\title{
Large variation in growth-limiting factors for marine heterotrophic bacteria in the Arctic waters of Spitsbergen $\left(78^{\circ} \mathrm{N}\right)$
}

\author{
Olav Vadstein* \\ Norwegian University of Science and Technology (NTNU), Department of Biotechnology, 7491 Trondheim, Norway
}

\begin{abstract}
Growth-limiting factors for heterotrophic bacteria were evaluated in euphotic coastal and fjord waters at 5 stations at Spitsbergen $\left(78^{\circ} \mathrm{N}\right)$. The study was done in late summer and comprised measurements of natural concentrations of nutrients, and bioassays in which changes in cell numbers and biomass production were the response variables after the addition of glucose (C), inorganic nitrogen ( $\mathrm{N}$; ammonium and nitrate) and inorganic phosphorus ( $\mathrm{P}$; phosphate), alone or in combination. The temperature at all 5 stations was similar, and the concentrations of dissolved inorganic $\mathrm{N}$ and $\mathrm{P}$ were so low that they could limit growth. Concentrations of particulate $\mathrm{C}, \mathrm{N}$ and $\mathrm{P}$ were higher at 2 northernmost stations, indicating higher total biomass and stronger competition between bacteria and phytoplankton. The amendments did not elicit a response in terms of cell numbers, probably due to longer response times or high mortality. For biomass production (leucine incorporation), significant effects of the amendments were observed at 3 out of the 5 stations. Mineral nutrient limitation ( $\mathrm{N}$ and $\mathrm{P}$ ) was detected at the 2 high-biomass stations, and carbon limitation was detected once. For the 2 coastal stations, more than 1 limiting factor (dual limitation) was recorded, with $\mathrm{C}$ and $\mathrm{P}$ as secondary limiting factor. No correlation was found between the species composition of the communities and the response in the bioassays. The spatial variability in the responses of heterotrophic bacteria to the addition of resources within a narrow time window reveals that we have insufficient knowledge to predict the consequences of a scenario in which warming occurs in Arctic areas. This lack of knowledge makes it impossible to predict the type of interaction between heterotrophic bacteria and phototrophs, and thus the implications of warming for food web functionality and stability.
\end{abstract}

KEY WORDS: Heterotrophic prokaryotes $\cdot$ Heterotrophic bacteria $\cdot$ Limiting factor $\cdot$ Growth $\cdot$ Arctic $\cdot$ Community structure

Resale or republication not permitted without written consent of the publisher

\section{INTRODUCTION}

Dissolved organic carbon (DOC) in the sea represents a carbon pool that is comparable in size to carbon dioxide $\left(\mathrm{CO}_{2}\right)$ in the atmosphere, and $\mathrm{CO}_{2}$ in the atmosphere is in equilibrium with the $\mathrm{CO}_{2}$ in surface seawater (Hedges 2002). Thus, understanding the regulation of production and mineralization of DOC in seawater is fundamental to comprehending the global carbon cycle. Whereas all organisms produce DOC, heterotrophic prokaryotes (hereafter called heterotrophic bacteria) are the main consumers of DOC. Whether bacterial production is limited by the avail- ability of carbon (C) or other factors will influence the rate of DOC consumption, and thus $\mathrm{CO}_{2}$ production. Consequently, whether or not $\mathrm{C}$ limits the growth of heterotrophic bacteria is a key factor that determines the extent to which the ocean acts as a trap for carbon.

Heterotrophic bacteria are normally limited by the availability of phosphorus (P) in boreal lakes (Vadstein 2000). For brackish and marine bacteria fewer data exist, and these data are not conclusive in terms of the limiting factor for these organisms (e.g. Kivi et al. 1993, Thingstad et al. 1993, Elser et al. 1995, Rivkin \& Anderson 1997, Sala et al. 2002, Teira et al. 2010). Data for polar marine areas are particularly scarce, and there 
is a discussion on which factors limit the activity of heterotrophic bacteria in these waters (e.g. Pomeroy \& Deibel 1986, Thingstad et al. 2002, Kirchman et al. 2009). In most marine areas, DOC accumulates in the euphotic zone during the productive season to approximately twice the level of that in the deeper waters (see Thingstad et al. 1997). Thus, production of DOC exceeds consumption, and as a consequence DOC is buried in deep waters when the stratification is terminated and the water column is mixed. Deep water may therefore function as a carbon trap.

Arctic marine areas seem to have been among those ecosystems that are the most responsive to ongoing global warming, and a knowledge of the response of these areas to changes in organic carbon load, and to changes in the availability of inorganic nutrients, is essential for predicting changes in the competition between phototrophs and heterotrophic bacteria - and for predicting effects on the global carbon cycle. These regimes may change with warming due to an increased input of DOC from rivers, reduced vertical transport of inorganic nutrients (due to increased vertical stability), and changes in the availability of light due to reduced ice cover.

The aim of the present study was to investigate which chemical macronutrient(s) limit the growth of heterotrophic bacteria in Arctic marine waters, and to evaluate the extent to which bacterial community structure correlates with the growth-limiting factor. The investigation was carried out at 5 stations, on the coast and in fjords, at Spitsbergen $\left(78^{\circ} \mathrm{N}\right)$. Limiting factors were evaluated by measurements of natural concentrations of nutrients and by nutrient amendment bioassays. Bioassays monitored the response to the addition of organic carbon, inorganic nitrogen and inorganic phosphorus. The composition of the bacterial community was characterized by using denaturing gradient gel electrophoresis (DGGE) to analyze the polymerase chain reaction (PCR) products obtained by amplifying a fragment of the 16S rRNA gene.

\section{MATERIALS AND METHODS}

Localities and sampling. The stations were selected to cover a limited area, with both coastal and fjord waters sampled within a short period of time. All stations were on the west coast of Spitsbergen (Fig. 1), with 2 coastal stations (Stns C1 and C2) and 3 fjord stations (Stns F1, F2, F3). All stations were located between 78 and $79^{\circ} \mathrm{N}$, and samples were taken within 1 wk (2 to 9 August 2007). Water was collected between 06:00 and 11:00 h at a depth of 3 to $5 \mathrm{~m}$, transferred to acid-washed and station-water-rinsed bottles, protected from direct sunlight, and kept at ambient temperature. Note that, at these locations, there are $24 \mathrm{~h}$ of sunlight at this time of the year. At the coastal stations, water was collected with a submersible centrifugal pump, with no metal parts in contact with the water-flow, whereas water from Stns F2 and F3 was

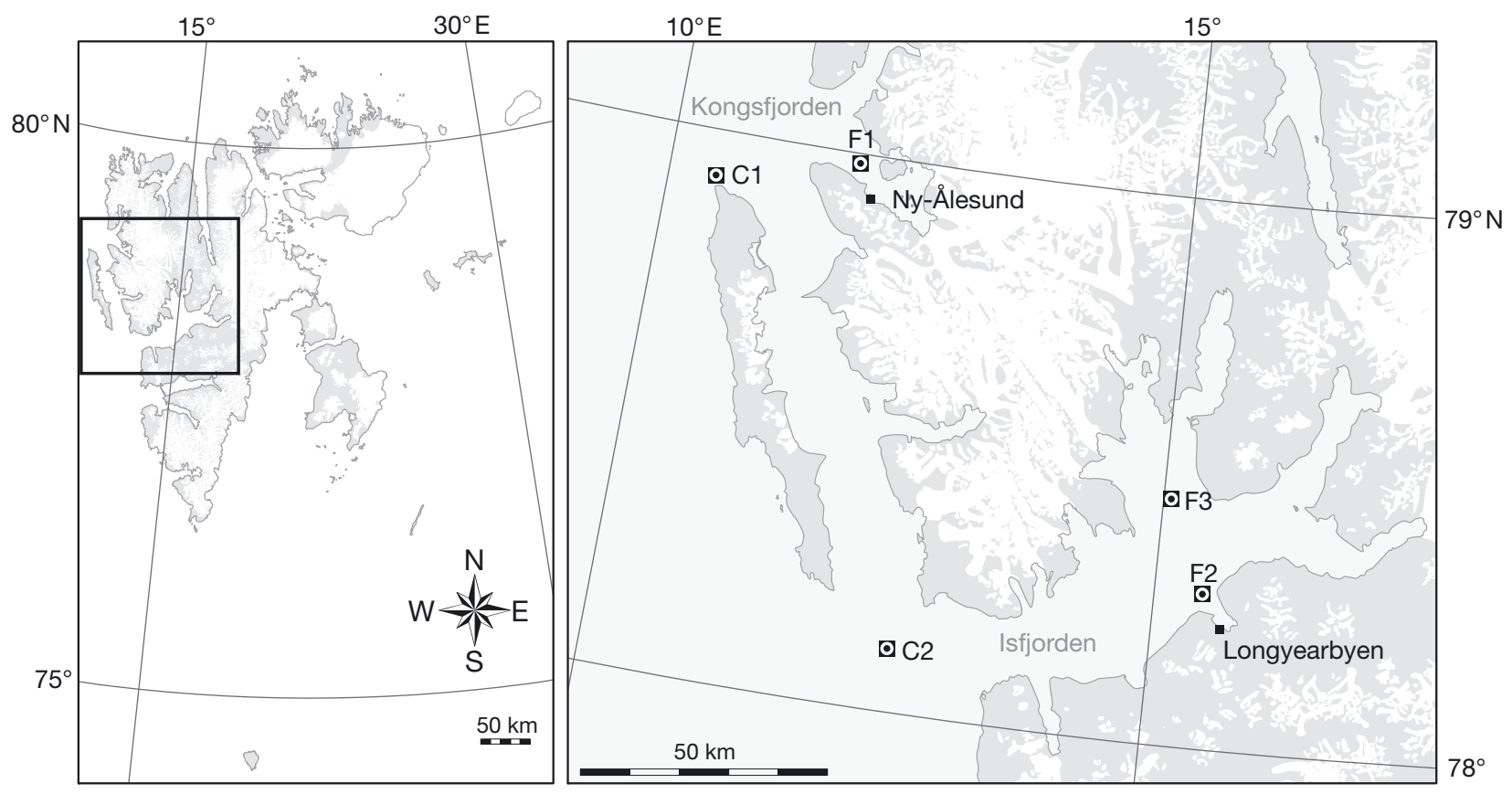

Fig. 1. Svalbard, with insert showing the part of Spitsbergen where the samples were taken. The sampling stations were: F1 (Kongsfjord, $78^{\circ} 59^{\prime} \mathrm{N}, 11^{\circ} 47^{\prime} \mathrm{E}$ ), F2 (Isfjord, 78 $17^{\prime} \mathrm{N}, 1^{\circ} 26^{\prime} \mathrm{E}$ ), F3 (Nordfjord, 78 $27^{\prime} \mathrm{N}, 1^{\circ} 04^{\prime} \mathrm{E}$ ), C1 (Coast Kongsfjord, $78^{\circ} 55^{\prime} \mathrm{N}, 10^{\circ} 27^{\prime} \mathrm{E}$ ) and $\mathrm{C} 2$ (Coast Isfjord, $\left.78^{\circ} 07^{\prime} \mathrm{N}, 12^{\circ} 42^{\prime} \mathrm{E}\right)$; for more information see Table 1 
collected with a Rutner sampler. Water was collected from Stn F1 for a mesocosm experiment (Thingstad et al. 2008). Translucent polyethylene tanks (volume $1 \mathrm{~m}^{3}$ ) were filled with water from the fjord to a volume of 7001 using a submersible centrifugal pump, brought to shore, and sampled the following day. The differences in sampling procedure are assumed not to affect the results.

Bioassay incubation for evaluation of limiting factor. The effect of adding organic carbon $\left(\mathrm{C}_{i}\right.$ glucose), inorganic nitrogen $\left(\mathrm{N}_{;}\right.$ammonium + nitrate in a $1: 1$ molar ratio) or inorganic phosphorus $\left(\mathrm{P}_{;}\right.$orthophosphate) was examined using bacterial production as a response variable. Water (0.5 l) was added to 5 plastic bags within $1 \mathrm{~h}$ of sampling. One of the bags served as a control, with zero addition. One bag received carbon $\left(\mathrm{C}_{i} 480 \mu \mathrm{M}\right)$, another received nitrogen $\left(\mathrm{N}_{;} 10 \mu \mathrm{M}\right)$, and a third received phosphorus $\left(P_{;} 5 \mu \mathrm{M}\right)$; the final bag received all 3 nutrients (CNP; 480, 10 and $5 \mu \mathrm{M}$ ). The amounts of added nutrient were sufficient for several doublings in biomass. The samples were incubated at in situ temperatures for $22 \mathrm{~h}$ before measurements of bacterial production and sampling for counts of bacteria. Previous experiments have shown no significant differences between replicates in such bioassay experiments (author's unpubl. results); thus, only analytical replication was done.

Analytical methods. Dissolved inorganic ammonia, nitrate and phosphate were measured in samples filtered through pre-combusted $\left(450^{\circ} \mathrm{C}, 4 \mathrm{~h}\right)$ and acid-washed (10\% $\mathrm{HCl}$ ) GF/F glass-fibre filters (Whatman). Samples were kept frozen $\left(-20^{\circ} \mathrm{C}\right)$ until analysis, in accordance with Grasshoff et al. (1983). For analysis of particulate carbon, nitrogen and phosphorus, the material collected on the GF/F glass-fibre filters was used (stored at $-20^{\circ} \mathrm{C}$ ). Carbon and nitrogen were analyzed with a Carlo Erba Element Analyser, and phosphorus was analyzed in accordance with Grasshoff et al. (1983).

For quantification of bacterial densities, water was fixed with paraformaldehyde $(0.5 \%$ final conc.), frozen in liquid nitrogen, and kept at $-20^{\circ} \mathrm{C}$ before processing. The abundance of heterotrophic bacteria was quantified, after the DNA was stained (SYBR Green I, Molecular Probes), in a FACSScan flow cytometer (Becton Dickinson) equipped with a laser supplying $15 \mathrm{~mW}$ at $488 \mathrm{~nm}$ and with a standard filter set-up (Marie et al. 1999). The clear bimodal distribution of DNA fluorescence intensity was used to classify bacteria into 2 categories: cells with a high content of DNA and cells with a low content of DNA. To calculate biomass from cell densities, 0.02 pg C per cell was assumed (author's unpubl. results).

The production of biomass by heterotrophic bacteria was estimated by incorporation of ${ }^{3} \mathrm{H}$ leucine into macromolecules (protein biosynthesis). Radioactive leucine was added to the samples at a final concentration of $20 \mathrm{nM}$, incubated for $1 \mathrm{~h}$ at ambient temperature $\left( \pm 1^{\circ} \mathrm{C}\right)$, stopped by addition of trichloracetic acid (TCA), and processed by the centrifugation method (Simon \& Azam 1989). Incorporation of ${ }^{3} \mathrm{H}$ was quantified by liquid scintillation counting, and the production of biomass by heterotrophic bacteria was quantified on a carbon basis and calculated in accordance with Kirchman (1993).

Characterization of the bacterial community structure. For the characterization of bacterial community structure by DGGE, a $50 \mathrm{ml}$ sample was concentrated by filtering onto a $0.2 \mu \mathrm{m}$ Dynagard hollow-fibre syringe filter (Microgon). Care was taken to remove excess water, and samples were stored at $-20^{\circ} \mathrm{C}$ before processing. DNA was isolated from the Dynagard filter using the DNeasy Tissue Kit (Qiagen). A modified version of the DNeasy bacteria protocol was used by including an extra initial lysis step (enzymatic lysis buffer with $20 \mathrm{mM}$ Tris-HCl [pH 8.0], 2 mM EDTA, 1.2\% Triton X-100 and $20 \mathrm{mg} \mathrm{ml}^{-1}$ lysozyme) and 2 elutions of the Dynagard filter and the DNeasy column. The DNA concentration in the extracts was measured with a NanoDrop spectrophotometer (Thermo Fisher Scientific).

The V3 region of bacterial 16S rDNA was amplified using PCR with the forward primer 338f (5'-ACT CCT ACG GGA GGC AGC AG) (Øvreås et al. 1997) and the reverse primer PRU517r (5'-ATT ACC GCG GCT GCT GG) (Muyzer et al. 1993). A 40-nucleotide GC clamp (5'CGC CCG CCG CGC GCG GCG GGC GGG GCG GGG GCA CGG GGG G) (Muyzer et al. 1993) was attached to the $5^{\prime}$ end of the forward primers. The $50 \mu \mathrm{l}$ reaction mixture contained sterile distilled water, $10 \times$ PCR buffer (Promega), deoxynucleoside triphosphates (200 nM each), primers (2 $\mu \mathrm{M}$ each), $7.5 \mu \mathrm{g}$ bovine serum albumin (Sigma), $0.5 \mathrm{mM} \mathrm{MgCl}, 0.04 \mathrm{U}$ Taq DNA polymerase (Promega), and $2.5 \mu$ l template ( $10 \mathrm{ng})$. The PCR amplification was performed with an initial denaturation step of $95^{\circ} \mathrm{C}$ for $4 \mathrm{~min}$, followed by 30 cycles of denaturation at $95^{\circ} \mathrm{C}$ for $30 \mathrm{~s}$, annealing at $55^{\circ} \mathrm{C}$ for $1 \mathrm{~min}$, and an elongation step of $72^{\circ} \mathrm{C}$ for $1.5 \mathrm{~min}$. Each reaction ended with an elongation step at $72^{\circ} \mathrm{C}$ for $30 \mathrm{~min}$ to avoid duplex bands (Janse et al. 2004). The amplification products were checked for length and purity on a $1.5 \%$ agarose gel.

The DGGE was performed with an Ingeny phorU system (Ingeny). PCR products were loaded onto $8 \%$ (w/v) polyacrylamide gels in $0.5 \times$ TAE buffer cast with a stacking gel ( $0 \%$ denaturant) on top of a denaturing gradient from 40 to $60 \%$. The electrophoresis was run at a constant voltage of $100 \mathrm{~V}$ at $60^{\circ} \mathrm{C}$ for $17 \mathrm{~h}$ in $0.5 \times$ TAE buffer, and post-stained for $1 \mathrm{~h}$ with SYBR Gold (1:10000 dilution, Molecular Probes). The gel was visualized and photographed with a G-box (Syngene). The band pattern for each sample was quantified using 
the program Gel2k provided by Svein Norland (Department of Biology, University of Bergen, Norway), and values for each peak were transformed to a percentage of the sum peak intensity.

Calculations and statistics. Specific growth rates $\left(\mathrm{d}^{-1}\right)$ of the bacterial communities were calculated as the natural logarithm of the ratio (biomass + production $\mathrm{h}^{-1}$ ):(biomass $\times 24$ ). The relative responses in leucine incorporations (R) were calculated for any amended treatment $(\mathrm{A})$ in a way that assigned treatment $\mathrm{Z}$ to 0 and treatment $\mathrm{CNP}$ to 1 , according to:

$$
\mathrm{R}=\frac{\mathrm{A}-\mathrm{Z}}{\mathrm{CNP}-\mathrm{Z}}
$$

Comparisons of stations and treatments were made using analysis of variance (ANOVA). When indications of differences between stations were detected, a multiple comparison test was done using the Tukey procedure. For evaluation of leucine incorporation in the bioassays, ANOVA was performed directly on the leucine incorporation data. For evaluation of responses to nutrient additions, the hypothesis of no response compared to the no-addition treatment $(\mathrm{Z})$ was tested by calculations of contrast. For calculations of dissimilarity of DGGE patterns we used the Bray-Curtis index. ANOVA and Bray-Curtis analysis were carried out using Systat (version 12). To compare similarity in DGGE patterns versus responses to nutrient amendment, a Mantel test was performed. For the bioassay data, both the original data and the relative responses (excluding $\mathrm{Z}$ and CNP treatments, as they are identical for all stations) in leucine incorporation were used as input data, and calculations were done in $\mathrm{R}$ using the vegan package (Oksanen et al. 2008).

\section{RESULTS}

\section{Physicochemical characteristics of the localities}

The temperature at the 5 stations averaged $7.1^{\circ} \mathrm{C}$, with a span of $<1^{\circ} \mathrm{C}$, whereas the salinity varied

Table 1. Overview of location, position, surface temperature, salinity and dissolved inorganic nutrients (orthophosphate and nitrate) for the sampled stations. The limit of detection for orthophosphate is $0.3 \mu \mathrm{g} \mathrm{P} \mathrm{l}^{-1}$. Ammonia was below the limit of detection at all stations $\left(<1 \mu \mathrm{g} \mathrm{N}^{-1}\right)$

\begin{tabular}{|llcrrrr|}
\hline Stn & Location & Position & $\begin{array}{c}\text { Temp. Salinity } \\
\left({ }^{\circ} \mathrm{C}\right)\end{array}$ & $\begin{array}{c}\mathrm{PO}_{4} \\
(\mathrm{psu})\end{array}$ & $\begin{array}{c}\mathrm{NO}_{3} \\
\left(\mu \mathrm{P} \mathrm{l}^{-1}\right)\end{array}$ \\
& & $\left.\mu \mathrm{N} \mathrm{N} \mathrm{l}^{-1}\right)$ \\
\hline F1 & Kongsfjord & $78^{\circ} 59^{\prime} \mathrm{N}, 11^{\circ} 47^{\prime} \mathrm{E}$ & 7.1 & 29.0 & $<0.3$ & 5.2 \\
$\mathrm{C} 1$ & Coast Kongsfjord & $78^{\circ} 55^{\prime} \mathrm{N}, 10^{\circ} 27^{\prime} \mathrm{E}$ & 7.2 & 31.9 & 0.5 & 4.4 \\
$\mathrm{C} 2$ & Coast Isfjord & $78^{\circ} 07^{\prime} \mathrm{N}, 12^{\circ} 42^{\prime} \mathrm{E}$ & 7.2 & 33.1 & 0.5 & 3.6 \\
F2 & Isfjord & $78^{\circ} 17^{\prime} \mathrm{N}, 15^{\circ} 26^{\prime} \mathrm{E}$ & 6.7 & 31.6 & $<0.3$ & 3.7 \\
F3 & Nordfjord & $78^{\circ} 27^{\prime} \mathrm{N}, 15^{\circ} 04^{\prime} \mathrm{E}$ & 7.5 & 30.1 & $<0.3$ & 3.8 \\
\hline
\end{tabular}
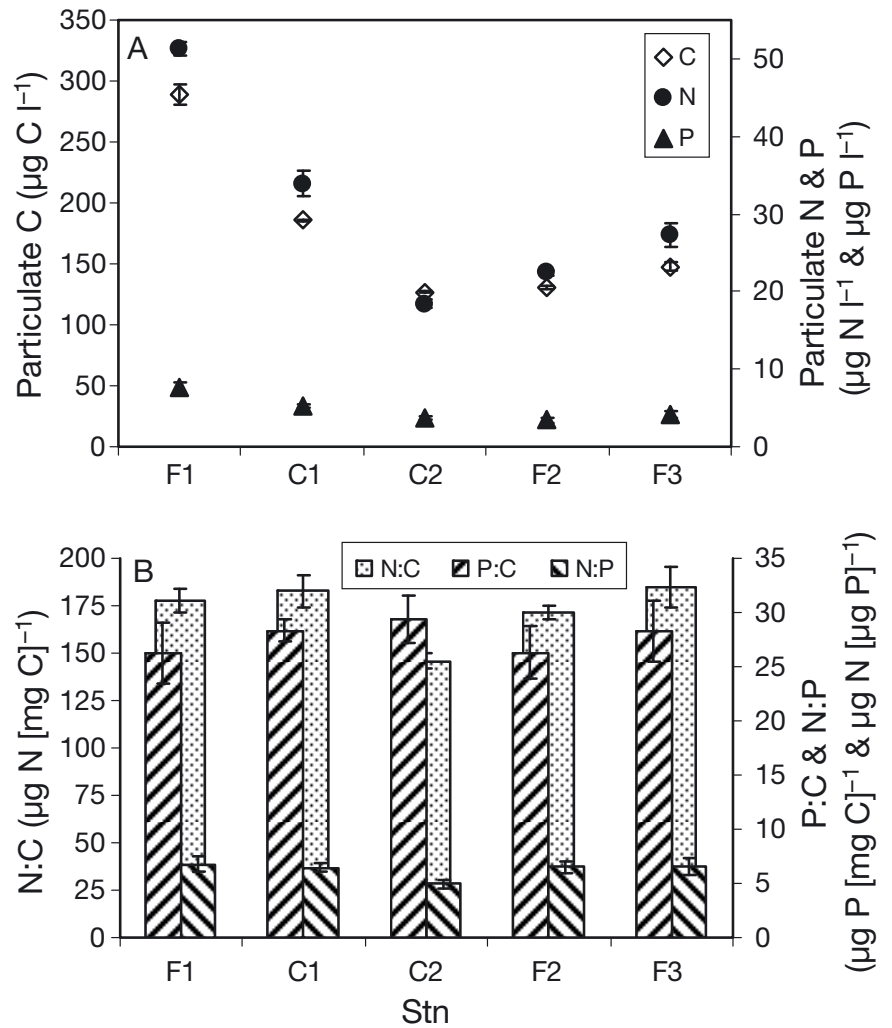

Fig. 2. (A) Concentrations of particulate carbon (C), nitrogen (N) and phosphorus (P). (B) Elemental ratios for the different stations: ratios for $\mathrm{N}: \mathrm{C}$ on left axis, and $\mathrm{P}: \mathrm{C}$ and $\mathrm{N}: \mathrm{P}$ on right axis. (For details of the sampling stations see Fig. 1.) Error bars are $\pm \mathrm{SE}$

between 29 and 33 psu and averaged 31 psu (Table 1). The tidal range in the area was 1.0 to $1.5 \mathrm{~m}$ during the investigation period. At all stations the ammonium concentration was below the limit of detection $(<1 \mu \mathrm{g}$ $\mathrm{N}^{-1}$ ); moreover, the concentrations of $\mathrm{PO}_{4}{ }^{3-}$ and $\mathrm{NO}_{3}{ }^{-}$ (Table 1) were so low that they potentially could be limiting for growth (Reay et al. 1999, Vadstein 2000). The concentrations of particulate $\mathrm{C}$ and $\mathrm{P}$ varied 2 -fold

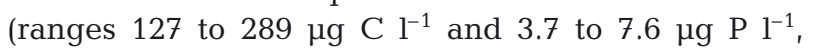
respectively), whereas particulate $\mathrm{N}$

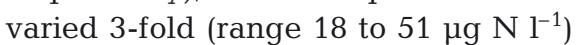
(Fig. 2A). A general trend was that concentrations were higher at the 2 northernmost stations (Stns F1 and C1). For particulate $\mathrm{C}$ and $\mathrm{N}$ this difference was statistically significant, and concentrations at Stn F1 were also significantly higher than at Stn C1. For particulate P, only Stn F1 had significantly higher concentrations compared with the other stations. Elemental ratios of particulate matter showed little variation (maximum range $37 \%$ ), 
and averaged $173 \pm 16 \mu \mathrm{g} \mathrm{N}(\mathrm{mg} \mathrm{C})^{-1}, 23 \pm 1.4 \mu \mathrm{g} \mathrm{P}(\mathrm{mg}$ $\mathrm{C})^{-1}$ and $6.3 \pm 0.7 \mu \mathrm{g} \mathrm{P}(\mu \mathrm{g} \mathrm{N})^{-1}( \pm \mathrm{SD} ;$ Fig. $2 \mathrm{~B})$. This corresponds to an overall average atomic $\mathrm{C}: \mathrm{N}: \mathrm{P}$ ratio of 112:14:1.

\section{Characterization of the bacterial community}

Bacterial densities were in the range 0.6 to $1.4 \times 10^{9}$ cells $\mathrm{l}^{-1}$ (Fig. 3), corresponding to biomasses between 12 and $29 \mathrm{\mu g} \mathrm{Cl}^{-1}$ (assuming $0.02 \mathrm{pg} \mathrm{C}$ per cell). As for concentrations of particulate constituents, the highest densities were observed at the 2 northernmost stations. The fraction of cells with a high content of DNA, an indicator of activity (Gasol et al. 1999), varied between 0.15 and 0.34 , and was linearly related to cell densities $\left(R^{2}=0.931, p=0.008\right)$. The composition of the bacterial community, as judged by DGGE, revealed a total of 33 distinct bands, of which none were unique for any sample. Twelve bands were found in all samples, and 2 were found in all but 1 sample (Fig. 4). Two bands were detected only at the 2 northernmost stations, and 1 was detected only in fjord samples.

The replicated sampling of Stn F1 (F1a and F1b) revealed a Bray-Curtis dissimilarity of 0.16 (Table 2); in the following dissimilarities $>2 \times$ this value is considered to be significantly different. On this basis, half of the comparisons between stations revealed no difference. The northern stations are similar, as are the 2 coastal stations. Moreover, Stn F3 is similar to the 2 coastal stations.

\section{Bioassay experiments}

Variation in cell densities at the termination of the bioassay experiments was 8 to $19 \%$ (mean 15\%), between the highest and lowest counts, within 1 experiment (data not shown). No significant differences due to amendments were observed; thus, the numerical

Table 2. Calculated Bray-Curtis dissimilarity coefficients for the composition of the communities of bacteria based on denaturing gradient gel electrophoresis (DGGE) band patterns (Fig. 4). Station abbreviations are explained in Table 1. Stns F1a and F1b are independent replicates taken from Stn 1 (see 'Results'). Significant dissimilarities (>0.318) are indicated in bold (see 'Results')

\begin{tabular}{|lccccc|}
\hline Stn & F1a & F1b & C1 & C2 & F2 \\
\hline F1b & 0.159 & & & & \\
C1 & 0.318 & 0.266 & & & \\
C2 & $\mathbf{0 . 3 9 9}$ & 0.309 & 0.241 & & \\
F2 & $\mathbf{0 . 5 5 5}$ & $\mathbf{0 . 5 2 0}$ & $\mathbf{0 . 4 5 1}$ & $\mathbf{0 . 3 6 1}$ & \\
F3 & $\mathbf{0 . 3 7 0}$ & $\mathbf{0 . 3 3 7}$ & 0.256 & 0.266 & $\mathbf{0 . 5 0 0}$ \\
\hline
\end{tabular}

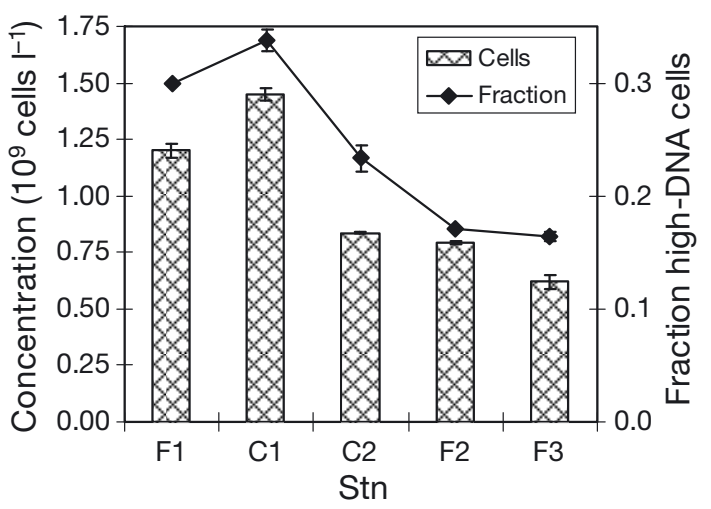

Fig. 3. Concentrations of heterotrophic bacteria (bars) and the share of bacteria with a high content of DNA (curve) for the different stations. (For details of the sampling stations see Fig. 1.) Error bars are $\pm \mathrm{SE}$

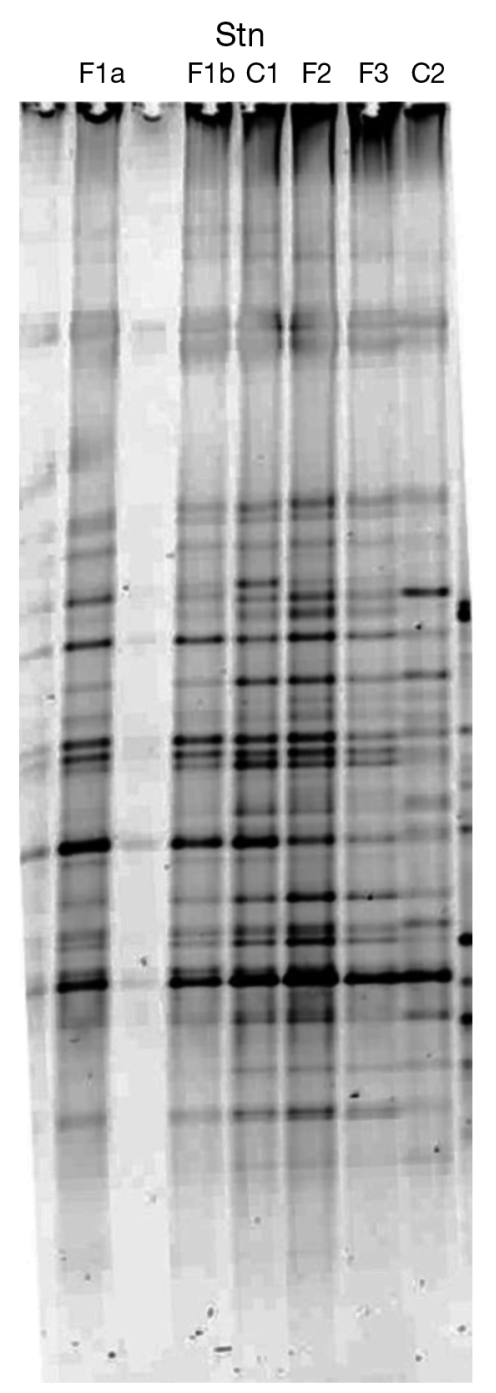

Fig. 4. Banding pattern obtained with denaturing gradient gel electrophoresis (DGGE) for the different stations. (For details of the sampling stations see Fig. 1.) For Stn F1, 2 independent samples were analyzed 

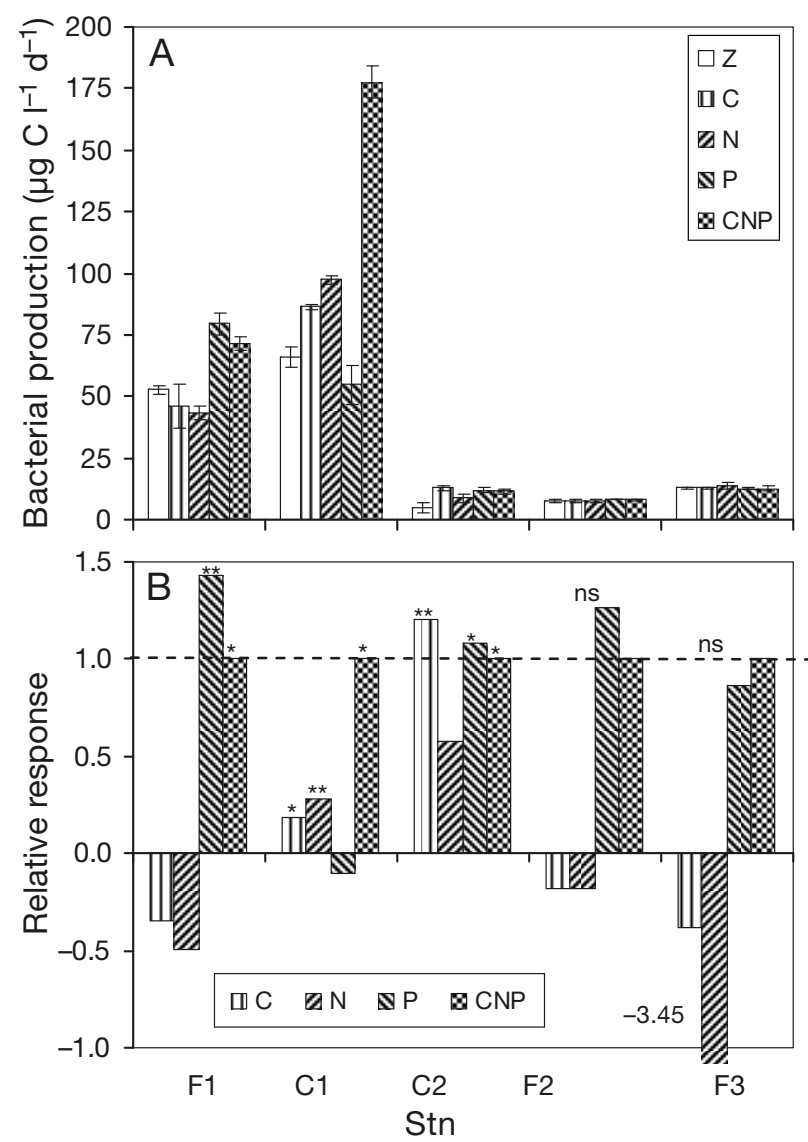

Fig. 5. Responses in production of bacterial biomass for the different bioassay experiments, showing stations and treatments. (For details of the sampling stations see Fig. 1.) $\mathrm{Z}=$ zero addition, $\mathrm{C}=$ addition of organic carbon, $\mathrm{N}=$ addition of inorganic nitrogen, $\mathrm{P}=$ addition of inorganic phosphorus, $\mathrm{CNP}=$ addition of all nutrients in combination. (A) Raw data $( \pm \mathrm{SE})$. (B) Relative responses calculated by defining the conditions with zero addition ( $\mathrm{Z}$ ) as zero and conditions with all nutrients added as 1 . Some values are negative as the production was lower with (than without) addition. Significant differences compared to zero $(\mathrm{Z})$ treatment are indicated (see also Table 3). ${ }^{*} \mathrm{p}<0.05,{ }^{* *} \mathrm{p}<0.01$

response was unsuitable as a response parameter under the conditions used. In contrast, bacterial production varied considerably within stations (Fig. 5A). For the unamended (Z) treatments, again, the northernmost stations deviated by having 4 to $13 \times$ (mean $5 \times$ ) higher production compared with the other 3 stations. Specific growth rates of the bacterial communities were in the range 0.3 to $2.1 \mathrm{~d}^{-1}$, assuming that the $\mathrm{Z}$ treatment represents natural conditions. The growth rates were $>2$ and $<1 \mathrm{~d}^{-1}$ for northern and southern stations, respectively.

The response to the additions of nutrients varied considerably between stations, from no response to more than a doubling in the production compared to the $\mathrm{Z}$ treatment. The $\mathrm{CNP}$ addition resulted in $\mathrm{a}>2.3 \times$
Table 3. p-values from comparisons with the zero addition $(\mathrm{Z})$ treatments of responses for the different nutrient addition treatments in cases where analysis of variance (ANOVA) indicated inhomogeneity. p-values from ANOVA for Stns F2 and F3 were 0.771 and 0.734 , respectively. Station abbreviations are explained in Table 1

\begin{tabular}{|lccc|}
\hline Treatment & Stn F1 & Stn C1 & Stn C2 \\
\hline $\mathrm{C}$ & 0.368 & 0.017 & 0.005 \\
$\mathrm{~N}$ & 0.208 & 0.001 & 0.115 \\
$\mathrm{P}$ & 0.003 & 0.150 & 0.017 \\
CNP & 0.022 & 0.017 & 0.014 \\
ANOVA p & 0.0013 & $<0.0001$ & 0.0317 \\
\hline
\end{tabular}

increase in production, compared to the $\mathrm{Z}$ treatment, for the 2 coastal stations, a $1.4 \times$ increase in the northern fjord station, and no response for the 2 southern fjord stations (Stns F2 and F3). To visualize the effect of the treatments for each station, responses were normalized in a manner which assigns the values 0 for the $\mathrm{Z}$ treatment (zero addition) and 1 for the CNP treatment (Fig. 5B; however, be aware of the masking of the absolute effect size). For the 2 coastal stations (Stns C1 and C2), more than 1 element seemed to give a response.

ANOVA revealed no statistically significant effect of nutrient additions for the 2 southern fjord stations (Stns F2 and F3; p > 0.7), whereas for the other 3 stations the effects were significant ( $p<0.03$; Table 3 ). For the northern fjord station (Stn F1) a clear P limitation is indicated (Table 3 ). For the 2 coastal stations, positive responses were recorded for both carbon and mineral nutrient additions (Table 3). For the northern coastal station (Stn $\mathrm{C} 1$ ), adding $\mathrm{N}$ gave a stronger response than adding $\mathrm{C}$, whereas for the southern station (Stn C2) the community responded more strongly to $\mathrm{C}$ than to $\mathrm{P}$ addition. For 2 of the stations (Stns F1 and C2) the response to addition of the limiting nutrient was larger than, or comparable to, the response to the addition of CNP (relative response $\geq 1$ ), whereas for Stn C1 the relative responses were $<30 \%$ of responses to the CNP treatment (Fig. 5B). Thus, only 2 of the 5 stations showed the same type of response (i.e. Stns F2 and F3, with no effect); for the rest of the stations the limitation varied considerably - both with respect to addition of the limiting factor and the response to the CNP treatment.

\section{DISCUSSION}

Assessment of growth-limiting factors for populations and communities is crucial for an understanding of the ecology and functioning of ecosystems. For planktonic heterotrophic bacteria in marine systems 
this is of particular interest due to the fact that they are major producers of $\mathrm{CO}_{2}$ globally (del Giorgio \& Duarte 2002), and that DOC consumption and respiration, versus DOC accumulation, may affect $\mathrm{CO}_{2}$ levels in the atmosphere. Moreover, the functionality of the interaction between phytoplankton and heterotrophic bacteria (competition/commensalism/mutualism) has major implications for the structure and function of the food web. From a paradigm with carbon/energy-limited heterotrophic bacteria acting as $\mathrm{CO}_{2}$ producers and re-mineralizers of inorganic nutrients, the last 3 decades have advanced and balanced our comprehension of growth limitation of heterotrophic bacteria. It is now established that mineral nutrient limitation is a normal phenomenon in many planktonic systems, and heterotrophic bacteria often compete with phytoplankton for mineral nutrients (Thingstad et al. 1998, Vadstein 2000). However, data on the limiting factors in Arctic systems are scarce (Thingstad et al. 2002).

It is not straightforward to assess growth-limiting factors (Hecky \& Kilham 1988) as regulation occurs from the level of the gene to the level of the ecosystem. In this study, concentrations of nutrients (dissolved and particulate nutrients) and bioassays were used in the assessment. In the bioassays, bacterial production was a better response variable than biomass increase, which may be due to both a too short time for response in cell densities (Olsen et al. 2006) and a strong regulation of bacterial biomass due to grazing or viral infections (Thingstad 2000).

Concentrations of inorganic $\mathrm{N}$ and $\mathrm{P}$ point to these mineral nutrients as possible limiting resources. For both ammonium and phosphate, the concentrations were below, or close to, the detection limits of $1 \mu \mathrm{g} \mathrm{N}$ $\mathrm{l}^{-1}$ and $0.3 \mu \mathrm{g} \mathrm{P}^{-1}$, respectively, whereas nitrate was around $4 \mu \mathrm{g} \mathrm{N}^{-1}$. All of these concentrations are in the range of those measured in strongly nutrient-limited bacterial cultures (Reay et al. 1999, Vadstein 2000). No attempts were made to measure DOC, as these measurements are hard to interpret in terms of concentrations of substrates that are easily accessible for bacteria (Søndergaard \& Middelboe 1995), and terrestrial DOC probably affected the stations differently. The elemental ratios of the particulate matter were fairly close to the Redfield ratio, with deviations of $-2,+9$ and $-12 \%$ for $\mathrm{N}: \mathrm{C}, \mathrm{P}: \mathrm{C}$ and $\mathrm{N}: \mathrm{P}$ ratios, respectively. This suggests a tendency towards $\mathrm{N}$ limitation of the system, but both particulate carbon and nitrogen are probably more affected by detritus than is particulate phosphorus (Olsen et al. 1986), and heterotrophic bacteria have far higher requirements for $\mathrm{P}$ than do phototrophs (Gismervik et al. 1996, Vadstein 2000). It is thus fair to conclude that the chemical variables measured are inadequate for evaluation of limiting factors, but they rule out neither $\mathrm{N}$ nor $\mathrm{P}$ limitation.
The bioassays indicate clear P limitation in 1 fjord sample (Stn F1) with an increase in the bacterial production due to $\mathrm{P}$ addition which was comparable to the nutrient-sufficient situation (100\% relative response). For the 2 coastal stations, mineral $\mathrm{N}$ limitation was strongest for Stn C1, and C limitation was strongest for Stn C2. There were also significant responses to the addition of $\mathrm{C}$ and $\mathrm{P}$, respectively, at these 2 stations. Thus, mineral nutrient limitation was more prominent than carbon/energy limitation at the localities investigated. Previous studies tend to suggest that C limitation is more common in polar waters (Church et al. 2000, Graneli et al. 2004), but numerical modelling and data reveal that the question of mineral nutrient versus carbon limitation depends on structuring bottom-up (resource) and top-down (predation) factors (Thingstad et al. 2002, 2008). An idealized size-structured food web model predicts mineral nutrient limitation of heterotrophic bacteria in situations with low predator biomass 3 trophic levels above the bacteria (specifically, copepods), resulting in low predation of phytoplankton and low regeneration rates of mineral nutrients (Thingstad et al. 2002). For the present study, no data exist on the biomass of competitors and predators. However, it is interesting to note that the 2 cases with mineral nutrient limitation (Stns F1 and C1) had higher concentrations of seston than did the cases with carbon limitation, or with no detected limitation. A high concentration of seston is an indication of a high biomass of phytoplankton due to low predation by copepods (Olsen et al. 2006), and thus our data support the model's predictions. A review by Kirchman et al. (2009) discusses limiting factors for heterotrophic bacteria in polar oceans, and concludes that temperature is a regulating factor at temperatures $<4^{\circ} \mathrm{C}$ and that the concentration of labile DOC (L-DOC) is a second regulating factor. As the concentration of $\mathrm{DOC}$, and most likely L-DOC, increases during the productive season (see Thingstad et al. 1997) one can hypothesise that seasonal carbon limitation is more likely to occur early, and mineral nutrient limitation late, in the productive season. Moreover, large calanoid copepods, such as the genus Calanus, migrate down around midseason, which, again, may increase the probability of mineral nutrient limitation as predation on phytoplankton is relieved and competition increases. Our August data are in accordance with such a hypothesis.

Data from the 2 coastal stations suggest 'dual limitation', meaning that more than 1 factor limited production-as revealed by single additions giving a significant response. Although dual limitation is a possibility for an organism on the scale of physiological adaptations, only 1 factor can limit biomass production in a population (Egli 1995). However, the systems studied here are communities composed of approximately 20 
dominating bacterial populations (Fig. 4), and dual limitation is thus a possibility as different populations of the community may be limited by different factors. In such a case one would expect neither of the single limiting factors to give a response similar to the full (CNP) treatment. This was the case for Stn C1, whereas for Stn $\mathrm{C} 2$ the response to $\mathrm{C}$ or $\mathrm{P}$ addition, alone, was not different from the full treatment. The reason for this observation is unclear.

Growth rates of 0.3 or $1.0 \mathrm{~d}^{-1}$ were observed for the 2 stations where no limiting factor was detected (Stns F2 and F3, respectively). Thus, the growth of these communities was below the maximum growth rate observed for the CNP treatment in the bioassays, and, consequently, was most likely limited by some resource not tested, and not by temperature. Limitation by micro-mineral nutrients (e.g. iron) is not likely, as both of these stations are fjord stations and therefore influenced by fresh water (Table 1). No hypothesis for the limiting factor can be provided, but experimental artefacts (like $>24 \mathrm{~h}$ response time) cannot be ruled out.

No clear pattern was observed between the BrayCurtis dissimilarity coefficients calculated from DGGE patterns and the responses to $\mathrm{C}, \mathrm{N}$ and $\mathrm{P}$ amendments. The northern mineral-nutrient-limited stations (Stns F1 and C1) and the 2 dual-limited coastal stations (Stns C1 and $\mathrm{C} 2$ ) have low dissimilarity, but this is also the case for Stn F3 with a lack of limitation. This was confirmed using a Mantel test $(r=0.234, p=0.293$ and $r=-0.0175$, $\mathrm{p}=0.562$ for original data and relative data, respectively). Surprisingly, this indicates that the different nutrient regimes which produced different limiting factors did not significantly affect either the inventory or dominance of species. Thus, factor(s) other than resource competition and competitive exclusion were controlling the community structure of the heterotrophic bacteria. Factors that could explain the composition of the community are viral infections (according to the 'Killing the Winner Hypothesis'; Thingstad 2000), the 'Intermediate Disturbance Hypothesis' (Connell 1978), or neutral theory (Hubbell 2001).

Both the experimental data and mathematical modelling reveal that heterotrophic bacteria may be limited by mineral nutrients under many food-web configurations and carrying capacities (trophic states) (Olsen et al. 2002, Thingstad et al. 2002, Vadstein et al. 2003). The data presented here reveal limitation by mineral nutrients at 2 of the 3 stations with detected resource limitation (Stns F1 and C1), and mineral nutrient/carbon dual limitation for the third (Stn C2). A capacity for increased consumption of DOC was indicated for 2 of the 5 stations (Stns C1 and C2). Spatial variability in the responses of heterotrophic bacteria to the addition of resources, within a narrow time window, reveals that we do not have the knowledge required to predict the consequences of a scenario in which Arctic areas undergo warming. This includes the phytoplanktonbacteria interaction and its consequences for the structure and functioning of the food web. Thus, we need more knowledge on carbon versus mineral nutrient limitation of heterotrophic bacteria in Arctic marine systems to be able to evaluate the role of heterotrophic bacteria for the global carbon cycle in a changing world.

Acknowledgements. I acknowledge the Sysselmannen and the crew on MS 'Nordsyssel' for taking me on board on the trip from Ny Ålesund to Longyearbyen, and for stopping for sampling; the logistic people at UNIS who made it possible to sample in Isfjorden and Nordfjorden; Professor G. Johnsen for helping me out at UNIS; and F. Thingstad and his colleagues for inviting me to participate in the mesocosm experiment in Ny Ålesund. K. Andresen, R. Inderberg Vestrum, A. Storsve and M. Schei made skilful contributions to the analytical work. S. Norland provided the Gel2k program, and The Norwegian Svalbard Society provided housing and hospitality while staying in Longyearbyen. Lasse M. Olsen provided helpful comments on an earlier version of the manuscript. This paper was finished while enjoying the friendly atmosphere in Andalucia at Instituto de Sciencias. Marinas de Andalucia under the hospitality of M. Yufera. This study is a part of the International Polar Year project 175939/S30 'PAME-Nor'.

\section{LITERATURE CITED}

Church MJ, Hutchins DA, Ducklow HW (2000) Limitation of bacterial growth by dissolved organic matter and iron in the Southern Ocean. Appl Environ Microbiol 66:455-466

> Connell JH (1978) Diversity in tropical rain forests and coral reefs. Science 199:1302-1310

del Giorgio PA, Duarte CM (2002) Respiration in the open ocean. Nature 420:379-384

Egli T (1995) The ecological and physiological significance of the growth of heterotrophic microorganisms with mixtures of substrates. Adv Microb Ecol 14:305-386

- Elser JJ, Stabler LB, Hassett RP (1995) Nutrient limitation of bacterial growth and rates of bacterivory in lakes and oceans: a comparative study. Aquat Microb Ecol 9: $105-110$

> Gasol JM, Zweifel UL, Peters F, Fuhrman JA, Hagström Å (1999) Significance of size and nucleic acid content heterogeneity as measured by flow cytometry in natural planktonic bacteria. Appl Environ Microbiol 65: 4475-4483

Gismervik I, Andersen T, Vadstein O (1996) Pelagic food webs and eutrophication of coastal waters: impact of grazers on algal development. Mar Pollut Bull 33:22-35

Craneli W, Carlsson P, Bertilsson S (2004) Bacterial abundance, production and organic carbon limitation in the Southern Ocean $\left(39-62^{\circ} \mathrm{S}, 4-14^{\circ} \mathrm{E}\right)$ during the austral summer 1997/1998. Deep-Sea Res II 51:2569-2582

Grasshoff K, Erhardt M, Kremling K (1983) Methods of seawater analysis. Verlag Chemie, Weinheim

> Hecky RE, Kilham P (1988) Nutrient limitation of the phytoplankton in freshwater and marine environments: a review of recent evidence on the effect of enrichment. Limnol Oceanogr 33:796-822 
Hedges JI (2002) Why dissolved organics matter. In: Hansell A, Carlson CA (eds) Biogeochemistry of marine dissolved organic matter. Academic Press, Amsterdam, p 1-33

Hubbell SP (2001) The unified neutral theory of biodiversity and biogeography. Princeton University Press, Princeton, NJ

Janse I, Bok J, Zwart G (2004) A simple remedy against artifactual double bands in denaturing gradient gel electrophoresis. J Microbiol Methods 57:279-281

Kirchman DL (1993) Leucine incorporation as a measure of biomass production by heterotrophic bacteria. In: Kemp PF, Sherr BF, Sherr EB, Cole JJ (eds) Handbook of methods in aquatic microbial ecology. Lewis Publishers, Boca Raton, FL, p 509-512

Kirchman DL, Morán XAG, Ducklow H (2009) Microbial growth in the polar oceans-role of temperature and potential impact of climate change. Nat Rev Microbiol 7: 451-459

Kivi K, Kaitala S, Kuosa H, Kuparinen J and others (1993) Nutrient limitation and grazing control of the Baltic plankton community during annual succession. Limnol Oceanogr 38:893-905

Marie D, Partensky F, Vaulot D, Brussaard CPD (1999) Enumeration of phytoplankton, bacteria and viruses in marine samples. In: Robinson JP, Darzynkiewicz Z, Dean PN, Orfao A and others (eds) Current protocols in cytometry. John Wiley, Chichester, p 11.11.1-11.11.15

Muyzer G, de Waal EC, Uitterlinden AG (1993) Profiling of complex microbial populations by denaturing gradient gel electrophoresis analysis of polymerase chain reactionamplified genes coding for 16S rRNA. Appl Environ Microbiol 59:695-700

Oksanen J, Kindt R, Legendre P, O'Hara B and others (2008) vegan: community ecology package. $\mathrm{R}$ package version 1.15-1. http://cran.r-project.org/web/packages/vegan/index. html

> Olsen Y, Jensen A, Reinertsen H, Børsheim Y, Heldal M, Langeland A (1986) Dependence of the rate of release of phosphorus by zooplankton upon the $\mathrm{P}: \mathrm{C}$ ratio in the food supply, as calculated by a recycling model. Limnol Oceanogr 31:34-44

Olsen LM, Reinertsen H, Vadstein O (2002) Can phosphorus limitation inhibit dissolved organic carbon consumption in aquatic microbial food webs? A microcosm study. Microb Ecol 43:353-366

> Olsen Y, Agusti S, Andersen T, Duarte CM and others (2006) A comparative study of responses in planktonic food web structure and function in contrasting European coastal waters exposed to experimental nutrient addition. Limnol Oceanogr 51:488-501

Øvreås L, Forney L, Daae FL, Torsvik V (1997) Distribution of bacterioplankton in meromictic lake Saelevannet, as determined by denaturing gradient gel electrophoresis of PCR-amplified gene fragments coding for 16S rRNA. Appl Environ Microbiol 63:3367-3373

Pomeroy LR, Deibel D (1986) Temperature regulation of bac-

Editorial responsibility: Fereidoun Rassoulzadegan, Villefranche-sur-Mer, France terial activity during the spring bloom in Newfoundland coastal waters. Science 233:359-361

Reay DS, Nedwell DB, Priddle J, Ellis-Evans JC (1999) Temperature dependence of inorganic nitrogen uptake: reduced affinity for nitrate at suboptimal temperatures in both algae and bacteria. Appl Environ Microbiol 65: 2577-2584

Rivkin RB, Anderson MR (1997) Inorganic nutrient limitation of oceanic bacterioplankton. Limnol Oceanogr 42:730-740

Sala MM, Peters F, Gasol JM, Pedros-Alio C, Marrase C, Vaque D (2002) Seasonal and spatial variations in the nutrient limitation of bacterioplankton growth in the northwestern Mediterranean. Aquat Microb Ecol 27: 47-56

Simon M, Azam F (1989) Protein content and protein synthesis rates of planktonic marine bacteria. Mar Ecol Prog Ser 51:201-213

Søndergaard M, Middelboe M (1995) A cross-system analysis of labile dissolved organic carbon. Mar Ecol Prog Ser 118: 283-294

Teira E, Martínez-García S, Calvo-Díaz A, Morán XAG (2010) Effects of inorganic and organic nutrient inputs on bacterioplankton community composition along a latitudinal transect in the Atlantic Ocean. Aquat Microb Ecol 60: 299-313

Thingstad TF (2000) Elements of a theory for the mechanisms controlling abundance, diversity, and biogeochemical role of lytic bacterial viruses in aquatic systems. Limnol Oceanogr 45:1320-1328

> Thingstad TF, Skjoldal EF, Bohne RA (1993) Phosphorus cycling and algal-bacterial competition in Sandsfjord, western Norway. Mar Ecol Prog Ser 99:239-259

Thingstad TF, Hagström ^, Rassoulzadegan F (1997) Accumulation of degradable DOC in surface waters: Is it caused by a malfunctioning microbial loop? Limnol Oceanogr 42:398-404

Thingstad TF, Zweifel UL, Rassoulzadegan F (1998) P limitation of heterotrophic bacteria and phytoplankton in the northwest Mediterranean. Limnol Oceanogr 43:88-94

Thingstad TF, Nielsen TG, Hansen AS, Levinsen H (2002) Control of bacterial production in cold waters. A theoretical analysis of mechanisms relating bacterial production and zooplankton biomass in Disko Bay, Western Greenland. Mar Ecol Prog Ser 228:15-24

> Thingstad TF, Bellerby RGJ, Bratbak G, Børsheim KY and others (2008) Counterintuitive carbon-to-nutrient coupling in an Arctic pelagic ecosystem. Nature 455:387-390

Vadstein O (2000) Heterotrophic, planktonic bacteria and cycling of phosphorus: phosphorus requirements, competitive ability and food web interactions. Adv Microb Ecol 16:115-168

Vadstein O, Olsen LM, Busch A, Andersen T, Reinertsen HR (2003) Is phosphorus limitation of heterotrophic bacteria and accumulation of degradable DOC a normal phenomenon in phosphorus limited systems? A microcosm study. FEMS Microbiol Ecol 46:307-316

Submitted: December 8, 2010; Accepted: March 3, 2011

Proofs received from author(s): May 24, 2011 